\title{
PENGARUH PERBEDAAN WAKTU PANEN TERHADAP KARAKTERISTIK KIMIA BIJI KECIPIR
}

\author{
[Effect of Harvesting Time on the Chemical Properties of Winged Bean Seed]
}

\author{
Rizki Dwi Setiawan ${ }^{1)}$, Fransiska Rungkat Zakaria ${ }^{2,4)}$, Azis Boing Sitanggang ${ }^{2,4) \star}$, Endang \\ Prangdimurti $^{2,4)}$, Dede Robiatul Adawiyah ${ }^{2,4)}$, dan Erniati ${ }^{3)}$ \\ 1) Program Studi Magister IImu Pangan, Sekolah Pascasarjana, Institut Pertanian Bogor, Bogor \\ 2) Departemen Ilmu dan Teknologi Pangan, Fakultas Teknologi Pertanian, Institut Pertanian Bogor, Bogor \\ 3) Fakultas Pertanian, Universitas Malikussaleh, Aceh \\ 4) Southeast Asian Food and Agricultural Science and Technology (SEAFAST) Center, Institut Pertanian Bogor, Bogor
}

Diterima 3 Desember 2018 / Disetujui 15 Oktober 2019

\begin{abstract}
In Indonesia, the utilization of winged bean seeds as a food source is very limited. Currently there is inadequate information on the characteristics of the seeds, especially the chemical properties associated with its maturity. This research aimed to analyze the chemical properties of winged bean obtained from different harvesting time. Three different harvesting times were investigated, i.e. eight (K1), twelve (K2), and as six (6) weeks after the first flowering stage as a control. $\mathrm{K} 1$ and $\mathrm{K} 2$ were dried at $40^{\circ} \mathrm{C}(24 \mathrm{~h})$ to mimic the conventional preparation of beans practiced in Indonesia, while K3 was unripe seeds commonly consumed fresh thus it is analyzed as fresh seeds. K1 and K2 have water content between 12.3-13.0\% (wb), ash content $4.7-4.8 \%(d b)$, lipid content $13.4-15.4 \%(d b)$, protein content $38.9-40.7 \%(d b)$, carbohydrate content $40.8-41.0 \%$ (db), total phenolic content 7.6 and $5.3 \mathrm{mg} \mathrm{GAE} / \mathrm{g}(\mathrm{db})$, antioxidant activity (IC 50 ) 558.3 and $511.1 \mu \mathrm{g} / \mathrm{mL}$, starch content 25.6-29.1\%, reducing sugar content $1.3-1.7 \mathrm{mg} / \mathrm{g}$. Meanwhile, the unripe winged bean seeds (K3) has water content of $75.5 \%$ (wb), ash content $5.0 \%$ (db), protein content $19.6 \%(d b)$, carbohydrate content $68.4 \%(d b)$, total phenolic content of $59.4 \mathrm{mg} \mathrm{GAE} / \mathrm{g}(\mathrm{db})$, antioxidant activity $\left(I_{50}\right) 485.6 \mu \mathrm{g} / \mathrm{mL}$, starch content $7.2 \%$ and reducing sugar $5.4 \mathrm{mg} / \mathrm{g}$. Based on these chemical properties and time efficiency, harvesting winged bean at 8 weeks (K1) was sufficient to produce winged bean potential as protein source, as well as a potential functional foods with good antioxidant activity, total phenolic content, low starch and reducing sugar.
\end{abstract}

Keywords: antioxidant, harvesting time, phenol, protein, starch, winged bean

\begin{abstract}
ABSTRAK
Di Indonesia pemanfaatan biji kecipir sebagai bahan pangan masih sangat rendah. Salah satu penyebabnya adalah belum banyak terdapat informasi mengenai karakteristik dari biji kecipir terutama sifat kimia biji kecipir pada berbagai tingkat kematangan. Penelitian ini bertujuan mengetahui komposisi kimia dari tiga umur panen biji kecipir. Digunakan biji kecipir dengan umur panen 8 minggu (K1), 12 minggu (K2) dan sebagai pembanding digunakan biji kecipir muda umur panen 6 minggu (K3) dari sejak tanaman kecipir muncul bunga pertama kali. Biji kecipir K1 dan K2 dilakukan pengeringan pada suhu $40^{\circ} \mathrm{C}(24$ jam) sebagai simulasi penjemuran yang biasa dilakukan oleh masyarakat sebelum dikonsumsi. Biji kecipir K3 merupakan biji kecipir yang biasa dikonsumsi oleh masyarakat sehingga dianalisis dalam bentuk segar. Hasil penelitian menunjukkan biji kecipir K1 dan K2 mengandung kadar air 12,3-13,0\% (bb), kadar abu 4,7-4,8\% (bk), kadar lemak 13,4-15,4\% (bk), kadar protein 38,9-40,7\% (bk), dan karbohidrat 40,8-41,0\% (bk), total fenol 7,6 mg GAE/g (K1) dan 5,3 mg GAE/g (K2) (bk), aktivitas antioksidan DPPH (IC ${ }_{50}$ ) sebesar 558,3 $\mu \mathrm{g} / \mathrm{mL}(\mathrm{K} 1)$ dan $511,1 \mu \mathrm{g} / \mathrm{mL}$ (K2), total pati $25,6-29,1 \%$ dan gula pereduksi $1,3-1,7 \mathrm{mg} / \mathrm{g}$. Biji kecipir K3 memiliki kadar air 75,5\% (bb), abu 5,0\% (bk), lemak 6,9\% (bk), protein 19,6\% (bk), karbohidrat 68,4\% (bk), total fenol 59,4 mg GAE/g (bk), aktivitas antioksidan ( $\left.\mathrm{IC}_{50}\right)$ 485,6 $\mu \mathrm{g} / \mathrm{mL}$, total pati $7,2 \%$ dan gula pereduksi sebesar $5,4 \mathrm{mg} / \mathrm{g}$. Berdasarkan karakteristik kimia dan efisiensi waktu panen, biji kecipir $\mathrm{K} 1$ berpotensi sebagai pangan tinggi protein, memiliki aktivitas antioksidan dan total fenol yang baik serta memiliki total pati dan gula pereduksi yang rendah sehingga menjanjikan sebagai pangan fungsional.
\end{abstract}

Kata kunci: antioksidan, biji kecipir, fenol, pati, protein, waktu panen

*Penulis Korespondensi:

E-mail: boing.lipan@apps.ipb.ac.id 


\section{PENDAHULUAN}

Biji kecipir (Psophocarpus tetragonolobus) merupakan salah satu kacang-kacangan sumber protein nabati yang dikonsumsi oleh masyarakat Indonesia. Kecipir merupakan salah satu jenis sayuran polong yang termasuk dalam famili kacangkacangan (Fabacceae). Pada tanaman kecipir hampir semua bagian dapat dimanfaatkan dan dikonsumsi seperti daun, polong, biji, bunga, dan umbi. Biji kecipir memiliki komponen asam amino esensial dan non-esensial yang tinggi (Mohtar et al., 2014). Di Indonesia saat ini sumber protein nabati yang berasal dari kacang-kacangan masih didominasi oleh kedelai, akan tetapi produksi kedelai di dalam negeri hanya mampu memenuhi sekitar $65,1 \%$ konsumsi domestik (Aldillah, 2015). Oleh karena itu saat ini Indonesia masih memiliki ketergantungan terhadap impor kedelai dilihat dari besarnya impor yang dilakukan sebesar 2,26 juta ton di tahun 2015 (BPS, 2017). Handayani et al. (2015) melaporkan bahwa dari 7 varietas tanaman kecipir memiliki produktivitas sekitar 2,58-8,94 ton/hektar, sedangkan apabila dibandingkan dengan kedelai hanya memiliki produktivitas sebesar 15,6 kuintal/hektar (Kementrian Pertanian, 2015).

Dalam beberapa tahun terakhir, penelitian mengenai biji kecipir sebagai sumber protein sudah mulai berkembang. Biji kecipir memiliki komponen senyawa asam amino yang menyerupai senyawa asam amino kedelai. Oleh karena itu biji kecipir telah banyak digunakan sebagai sumber protein pengganti dari kedelai. Wahyuni (2010) melaporkan bahwa total isofalvon pada biji kecipir lebih tinggi dibandingkan dengan kedelai dan terdiri dari factor-2isoflavone, daidzein, glysiteine dan genisteine. Beberapa penelitian yang sudah ada mengenai biji kecipir berada pada ekplorasi dan identifikasi komponen gizi utama seperti pada lemak (Mohanty et al., 2013) dan peptida biji kecipir (Yea et al., 2018). Penelitian lainnya menunjukkan aplikasi biji kecipir sebagai sumber protein pengganti kedelai seperti pada tahu, susu dan yoghurt (Budijanto et al., 2011; Wijaya et al., 2015) dan aplikasi pada produk seperti dalam pembuatan margarin (Makeri et al., 2019).

Di Indonesia kecipir digunakan dalam bentuk polong muda sebagai sayuran sehari-hari. Biji kecipir dengan umur panen matang ataupun setengah matang masih jarang dikonsumsi oleh masyarakat. Beberapa penelitian menunjukkan bahwa komponen fisiko-kimia dari tanaman dipengaruhi oleh banyak faktor, salah satu faktor utamanya adalah umur panen (Ogumo et al., 2018). Senyawa isofalvon pada tanaman dilaporkan tidak hanya dipengaruhi oleh faktor genetik, tetapi juga dipengaruhi oleh faktor lingkungan seperti lokasi dan musim panen (Lee dan Cho, 2012). Sampai saat ini belum ada penelitian yang melaporkan mengenai karakteristik kimia biji kecipir pada berbagai umur panen. Penelitian ini bertujuan untuk melihat karakteristik kimia yang terdiri dari komposisi proksimat, total fenol, aktivitas antioksidan, total pati dan gula pereduksi biji kecipir pada 3 umur panen yang berbeda. Penelitian ini diharapkan dapat memberikan informasi mengenai karakteristik kimia dari biji kecipir dengan umur panen yang berbeda sebagai dasar dalam mengembangkan biji kecipir sebagai pangan fungsional.

\section{BAHAN DAN METODE}

\section{Bahan}

Biji kecipir (Psophocarpus tetragonolobus) didapatkan dari petani lokal di Caringin, Bogor Jawa Barat dengan tiga umur panen yang berbeda yaitu biji kecipir dengan umur panen 8 minggu (K1), biji kecipir dengan umur panen 12 minggu (K2), dan sebagai pembanding digunakan biji kecipir dengan umur panen 6 minggu (K3) setelah tanaman kecipir muncul bunga pertama kali. Warna ketiga biji kecipir tersebut berturut-turut adalah coklat, hitam dan hijau. Biji kecipir disimpan dalam ruang pendingin $\left(4^{\circ} \mathrm{C}\right)$ hingga digunakan untuk analisis (Gambar 1$)$.

\section{Persiapan sampel}

Biji kecipir yang digunakan dalam penelitian ini terdiri dari tiga umur panen yang berbeda yaitu biji kecipir dengan umur panen 8 minggu (K1), 12 minggu (K2), dan sebagai pembanding digunakan biji kecipir muda dengan umur panen 6 minggu (K3) setelah masa berbunga tanaman pertama kali. Biji kecipir (K1) dan (K2) dilakukan pengeringan terlebih dahulu pada suhu $40^{\circ} \mathrm{C}$ selama 24 jam sebagai simulasi penjemuran yang biasa dilakukan oleh masyarakat sebelum dikonsumsi, sedangkan untuk biji kecipir K3 merupakan biji kecipir muda yang biasa dikonsumsi oleh masyarakat Indonesia sehingga dilakukan analisis dalam bentuk segar. Perbedaan kondisi awal pada sampel dilakukan dengan tujuan untuk mengetahui karakteristik kimia biji kecipir yang biasa dikonsumsi oleh masyarakat Indonesia saat ini. Semua sampel dilakukan analisis komposisi proksimat, total fenol, aktivitas antioksidan, total pati, dan kadar gula pereduksi.

\section{Analisis proksimat}

Komposisi proksimat yang dianalisis meliputi kadar air, abu, protein, lemak dan karbohidrat. Kadar air dianalisis menggunakan metode oven (BSN, 1992), kadar abu dianalisis menggunakan metode pengabuan kering (BSN, 1992). Kadar lemak dianalisis menggunakan metode soxhlet (AOAC, 2012) dan kadar protein dianalisis dengan metode Kjeldahl (AOAC, 2012). 


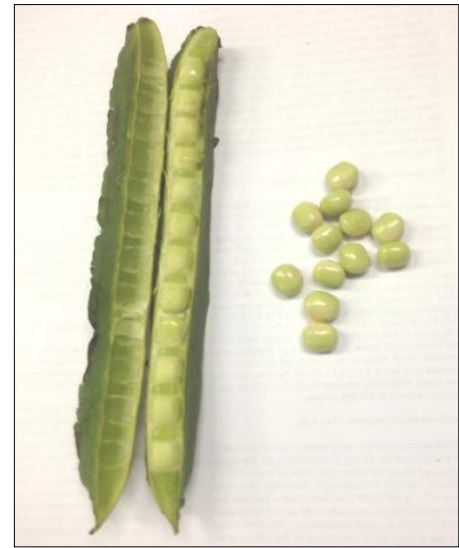

A

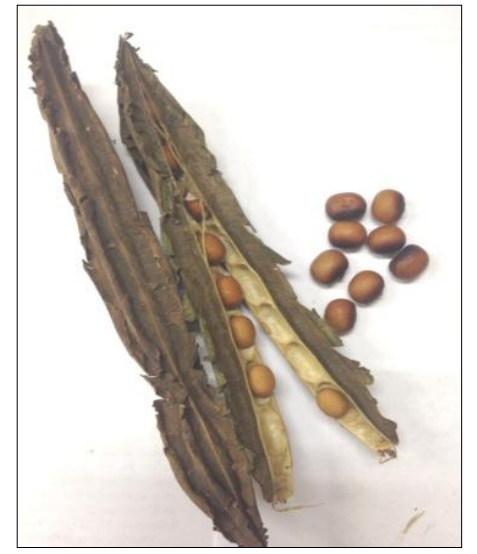

B

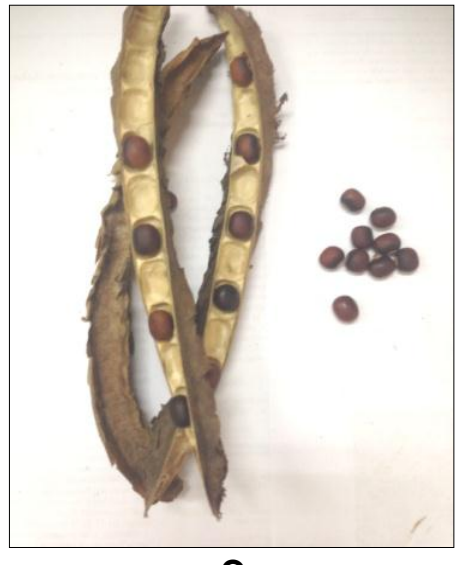

C

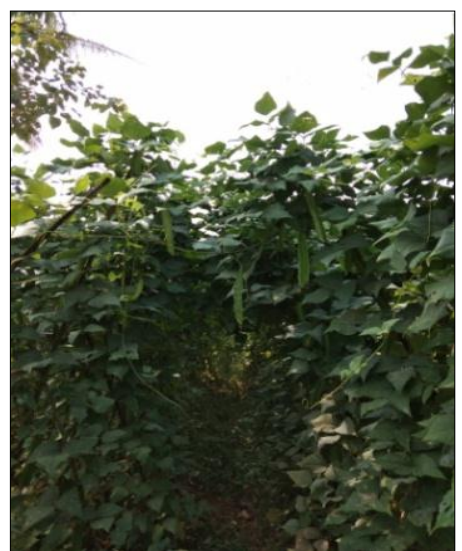

D

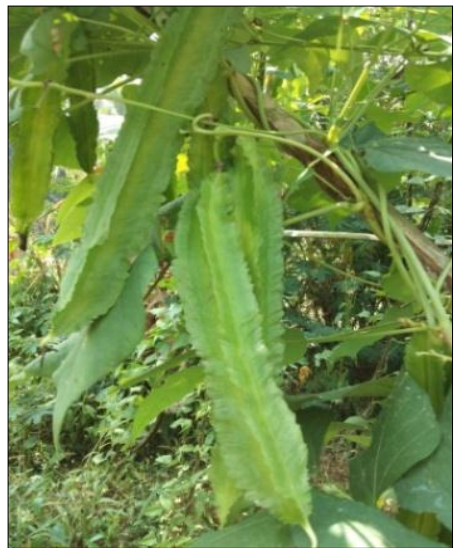

E

Keterangan: $A=$ Biji kecipir umur panen 6 minggu, $B=$ Biji kecipir umur panen 8 minggu, $C=$ Biji kecipir umur panen 12 minggu, $\mathrm{D}=$ Tanaman kecipir, $\mathrm{E}=$ Polong kecipir

\section{Gambar 1. Tanaman kecipir dan biji kecipir pada berbagai umur panen}

Sementara itu penentuan kadar karbohidrat dilakukan secara by different (basis kering) yaitu berdasarkan selisih dari angka 100 dengan persentase komponen lain (kadar abu, kadar lemak dan kadar protein sampel).

\section{Analisis total fenol (Hodzic et al., 2009)}

Kandungan total fenol dianalisis menggunakan pereaksi Folin-Ciocalteu. Sampel sebanyak $100 \mathrm{mg}$ ditambahkan etanol 95\% (Merck, Germany) $5 \mathrm{~mL}$. Campuran sampel kemudian disentrifus pada 3000 rpm selama 15 menit. Sebanyak $0,5 \mathrm{~mL}$ supernatan dimasukkan ke dalam tabung reaksi, kemudian ditambahkan 0,5 mL etanol $95 \%, 2,5 \mathrm{~mL}$ akuades, dan $2,5 \mathrm{~mL}$ pereaksi Folin-Ciocateu (Sigma Ltd.) $50 \%$. Campuran didiamkan selama 5 menit, lalu ditambahkan $0,5 \mathrm{~mL} \mathrm{Na} \mathrm{CO}_{3}$ (Merck, Germany) $5 \%$, campuran sampel kemudian ditempatkan dalam ruang gelap selama satu jam. Absorbansi larutan diukur menggunakan spektrofotometer UV-Vis (Hitachi U-2900, Japan) pada panjang gelombang
$725 \mathrm{~nm}$. Analisis kuantitatif total fenol dilakukan dengan membuat kurva standar asam galat (Sigma, Ltd). konsentrasi $(0,50,100,150,200$, dan 250 ppm), selanjutnya kadar total fenol sampel dihitung menggunakan kurva standar asam galat yang diperoleh. Kadar total fenol dihitung sebagai ekuivalen asam galat.

\section{Analisis aktivitas antioksidan (DPPH) (Salazar- Aranda et al., 2011)}

Tepung biji kecipir $(100 \mathrm{~g})$ diekstrak dengan metode maserasi mengunakan metanol (Merck, Germany) (3x600 mL) selama 2 jam pada suhu ruang. Ekstrak yang didapatkan kemudian disaring dan dipekatkan menggunakan rotary evaporator (Buchi R-300 EL, Switzerland). Sampel dalam etanol dibuat dalam berbagai konsentrasi (konsentrasi 125, 250, 500, 750, dan $1000 \mu \mathrm{g} / \mathrm{mL}$ ). Larutan standar DPPH (Sigma Ltd.) dibuat dalam konsentrasi 175 $\mu \mathrm{M}$ dalam etanol. Dalam total volume $2 \mathrm{~mL}$ masingmasing terdiri dari $1 \mathrm{~mL}$ larutan sampel, dan $1 \mathrm{~mL}$ 
larutan standar DPPH. Campuran diinkubasi selama 30 menit pada suhu ruang kemudian absorban diukur dengan menggunakan spektrofotometer UVVis pada panjang gelombang $517 \mathrm{~nm}$. Asam askorbat (Merck, Germany) digunakan sebagai pembanding dalam menangkap radikal bebas $\mathrm{DPPH}$. Kapasitas penangkapan radikal bebas dihitung sebagai persentase inhibisi terhadap DPPH (persentase scavenging effect) yaitu:

Inhibisi $(\%)=\frac{(\text { A blanko-A sampel })}{\text { A blanko }} \times 100 \%$

dimana, A adalah absorbansi. Aktivitas antioksidan dinyatakan dengan nilai $\mathrm{IC}_{50}$ yaitu konsentrasi sampel yang diperlukan untuk memberikan \% inhibisi sebesar $50 \%$.

\section{Total pati (Clegg, 1956)}

Total pati diukur dengan menggunakan metode Anthrone. Tepung biji kecipir sebanyak $65 \mathrm{mg}$ dicuci sebanyak 4 kali dengan $10 \mathrm{~mL}$ etanol $80 \%$, kemudian ditambahkan sejumlah $\mathrm{HCl}$ (Merck, Germany) untuk hidrolisis bahan. Sampel dipanaskan dengan menggunakan waterbath pada suhu $85^{\circ} \mathrm{C}$ selama 2,5 jam. Keasaman $\mathrm{pH}$ filtrat diukur dan diatur hingga cukup basa dengan penambahan $\mathrm{CaCO}_{3}$ (Merck, Germany). Setelah itu ditambahkan $\mathrm{Pb}$ asetat (Merck, Germany) dan kemudian disaring. Hasil saring filtrat kemudian ditera hingga $100 \mathrm{~mL}$. Ditambahkan Na-Oksalat (Merck, Germany) dan kemudian disaring kembali. Larutan glukosa (Sigma Ltd.) digunakan sebagai standar dengan konsentrasi 0 (blanko); 0,2; 0,4; 0,6; 0,8 dan $1 \mathrm{mg} / \mathrm{mL}$. Masingmasing diambil $1 \mathrm{~mL}$ dari larutan glukosa standar dan sampel kemudian tambahkan dengan cepat 5 $\mathrm{mL}$ pereaksi anthrone ke dalam masing-masing tabung reaksi. Tutup tabung reaksi dan vortex selama 30 detik. Tabung reaksi dipanaskan dalam waterbath $100^{\circ} \mathrm{C}$ selama 12 menit dan setelah itu didinginkan, kemudian absorban diukur dengan menggunakan spektrofotometer UV-Vis pada absorbansi $630 \mathrm{~nm}$.

\section{Kadar gula pereduksi (Başkan et al., 2016)}

Kadar gula pereduksi dianalisis menggunakan metode DNS. Sampel yang sudah dihaluskan sebanyak $2,5 \mathrm{~g}$, kemudian dicuci sebanyak 4 kali dengan $30 \mathrm{~mL}$ etanol $80 \%$ dan diambil bagian supernatannya. Supernatan ditambahkan Na-karbonat (Merck, Germany) kemudian dipanaskan pada suhu $85^{\circ} \mathrm{C}$ selama 30 menit dan setelah itu didinginkan terlebih dahulu. Hasil pemanasan disaring kemudian ditambahkan $\mathrm{Pb}$ asetat dan disaring kembali. Supernatan ditambahkan Na-Oksalat dan ditera hingga $100 \mathrm{~mL}$. Larutan disaring kembali dan dipindahkan ke dalam tabung reaksi secukupnya untuk digunakan. Sebanyak $3 \mathrm{~mL}$ pereaksi DNS ditambahkan pada sampel dan campuran kemudian dipanaskan selama 5 menit pada suhu $100^{\circ} \mathrm{C}$. Setelah larutan sampel dingin kemudian diukur dengan menggunakan spektrofotometer UV-Vis pada absorbansi $550 \mathrm{~nm}$. Kurva standar menggunakan larutan glukosa dengan konsentrasi $0,2-5,0 \mathrm{mg} / \mathrm{mL}$.

\section{Analisis data}

Analisis data dilakukan dengan prosedur sidik ragam (Analisis of Varian, ANOVA) dengan bantuan program SPSS 22. Apabila hasil uji sidik ragam menunjukkan adanya perbedaan maka dilanjutkan dengan uji jarak berganda Duncan pada taraf $5 \%$. Rancangan percobaan yang digunakan adalah rancangan acak lengkap (RAL) yang terdiri dari tiga jenis sampel dan 3 kali ulangan, yaitu $\mathrm{K} 1=$ biji kecipir yang dipanen pada umur 8 minggu, $\mathrm{K} 2=$ biji kecipir yang dipanen pada umur 12 minggu dan $\mathrm{K} 3=$ biji kecipir yang dipanen pada umur 6 minggu sejak tanaman muncul bunga pertama kali.

\section{HASIL DAN PEMBAHASAN}

\section{Komposisi proksimat}

Hasil analisis menunjukkan biji kecipir umur panen 8 (K2) dan 12 minggu (K3) memiliki kadar air berkisar 12,3-13,0\% (bb), kadar abu 4,7-4,8\% (bk), kadar lemak 13,4-15,4\% (bk), kadar protein 38,9$40,7 \%$ (bk), dan karbohidrat 40,8-41,0\% (bk). Uji Duncan menunjukkan bahwa perbedaan umur panen 8 minggu (K1) dan 12 minggu (K2) pada biji kecipir memberikan pengaruh nyata $(P<0,05)$ terhadap kadar lemak dan protein biji kecipir. Hal ini sesuai dengan penelitian yang dilakukan oleh Panahi dan Kherzi (2011), pada perlakuan yang sama, perbedaan umur panen memberikan pengaruh nyata terhadap komposisi proksimat dari kacang pistachio (Pistaciavera L.), semakin lama umur panen maka kadar air semakin rendah dan kadar lemak semakin tinggi. Lee et al. (2013) melaporkan pada kedelai dengan lima umur panen yang berbeda dan telah mengalami pengeringan menggunakan freeze dryer, didapatkan kadar lemak dan karbohidrat mengalami peningkatan dengan semakin lamanya umur panen sedangkan kadar protein kedelai mengalami peningkatan namun menurun pada akhir umur panen.

Perbedaan umur panen 8 minggu (K1) dan 12 (K2) minggu tidak memberikan pengaruh nyata $(P<0,05)$ terhadap kadar air biji kecipir, namun terjadi penurunan kadar air dengan semakin lama umur panen. Apabila dibandingkan dengan biji kecipir muda (K3), biji kecipir umur panen 6 minggu (K3) yang dianalisis dalam bentuk segar (tanpa dikeringkan), memiliki kadar air yang paling tinggi yaitu sebesar $75,53 \%$. Perbedaan umur panen K1 dan K2 tidak memberikan pengaruh nyata terhadap kadar abu biji 
kecipir, namun terjadi penurunan kadar abu dengan semakin lama umur panen. Hal yang sama dilaporkan oleh Wawire et al. (2012), terdapat penurunan beberapa kandungan mineral pada kacang tunggak. Semakin bertambahnya umur panen, semakin besar ukuran tanaman maka mineral atau zat hara yang diserap dari akar akan terbagi-bagi ke bagian lain.

Terdapat perbedaan nyata pada kadar lemak dan protein biji kecipir umur panen 8 minggu (K1) dan 12 (K2) minggu. Biji kecipir K1 memiliki kadar lemak yang lebih tinggi $(15,40 \%)$ dibandingkan dengan biji kecipir K2 (13,49\%). Mohanty et al. (2013) melaporkan bahwa asam lemak jenuh pada biji kecipir mengalami penurunan seiring dengan lamanya umur panen, tetapi asam lemak tidak jenuh (MUFA dan PUFA) mengalami peningkatan seiring dengan lamanya umur panen. Asam lemak jenuh pada biji kecipir muda sebesar $61,3 \%$ mengalami penurunan menjadi $34,7 \%$ pada biji kecipir matang, tetapi asam lemak tidak jenuh (MUFA dan PUFA) pada biji kecipir matang sebesar $62,3 \%$ mengalami peningkatan menjadi $75,5 \%$ pada biji kecipir matang sempurna (Mohanty et al., 2013). Pada penelitian ini dimungkinkan terjadi hal yang serupa dimana terjadi penurunan asam lemak jenuh yang lebih besar dibandingkan dengan terjadinya peningkatan asam lemak tidak jenuh (MUFA dan PUFA) sehingga memengaruhi penurunan kadar lemak total pada kedua umur panen biji kecipir. Lee et al. (2013) melaporkan kandungan asam lemak palmitat, stearat, dan linoleat merupakan asam lemak yang dominan pada kedelai hitam pada umur panen muda, tetapi kemudian menurun seiring dengan lamanya umur panen. Kadar lemak pada kedelai secara umum mengalami peningkatan seiring bertambahnya kematangan kacang kedelai (Saldivar et al., 2011). Kedua sampel biji kecipir memiliki kadar lemak yang lebih tinggi apabila dibandingkan dengan biji kecipir segar (K3) yaitu hanya sebesar $(6,94 \%)$.

Biji kecipir dengan umur panen 12 minggu (K2) $(40,70 \%)$ memiliki kadar protein yang lebih tinggi dibandingkan dengan biji kecipir umur panen 8 minggu (K1) (38,91\%). Tanaman berbiji akan menyimpan protein dalam biji sebagai upaya dalam pertumbuhannya. Penyimpanan protein ini menyediakan asam amino yang akan digunakan untuk germinasi dan pertumbuhan biji (Horax et al., 2010). Kadar protein kedua sampel jauh lebih tinggi apabila dibandingkan dengan biji kecipir segar (K3) yang hanya sebesar 19,62\%. Kadar protein biji kecipir pada penelitian ini (K1 dan K2) didapatkan lebih tinggi apabila dibandingkan dengan kadar protein biji kecipir yang dilaporkan oleh Yea et al. (2014) yaitu sebesar $25 \%$. Perbedaan kadar protein ini dimungkinkan karena terdapatnya perbedaan varietas atau spesies dan lingkungan tanaman. Kadar protein biji kecipir pada penelitian ini lebih tinggi apabila dibandingkan dengan kacang hijau yaitu sebesar 22-25\% (Pal et al., 2010) dan hampir sama dengan kadar protein pada kedelai sebesar 35,63\% (Palupi et al., 2015). Hal ini menunjukkan bahwa biji kecipir dapat digunakan sebagai sumber protein pengganti dari kacang kedelai.

Kadar karbohidrat biji kecipir mengalami sedikit kenaikan pada umur panen 8 minggu (K1) hingga umur panen 12 minggu (K2). Hal ini diduga karena terjadinya perubahan komponen dari golongan oligosakarida dan disakarida seperti rafinosa, stakiosa, verbaskosa, dan sukrosa. Obendorf et al. (2011) menyatakan bahwa rafinosa, stakiosa, verbaskosa, dan sukrosa merupakan karbohidrat yang dominan berada pada kacang kedelai. Perubahan komponen oligosakarida dan disakarida pada kedelai telah dilaporkan oleh beberapa peneliti lainnya (Saldivar et al., 2011; Lee et al., 2013). Komposisi proksimat biji kecipir pada berbagai umur panen yang berbeda dapat dilihat pada Tabel 1.

\section{Total fenol}

Senyawa fenolik memiliki peran vital untuk melawan senyawa reaktif oksigen spesies (ROS) yang dapat meminimalkan terjadinya kerusakan molekuler (Koley et al., 2014). Senyawa fenolik diketahui dapat meningkatkan aktivitas proliferasi limfosit limfa dan meningkatkan kapasitas antioksidan pada hati melalui peningkatan aktivitas enzim antioksidan (SOD, CAT, GPx) dan penurunan kadar malonaldehida (Zakaria et al., 2011). Analisis total fenol dilakukan dengan metode Folin-Ciocalteu dengan menggunakan spektrofotometer dan data disajikan dalam milligram ekuivalen asam galat. Kandungan total fenol pada biji kecipir dapat dilihat pada Tabel 1.

Tabel 1. Komposisi proksimat biji kecipir pada berbagai umur panen

\begin{tabular}{lccc}
\hline \multicolumn{1}{c}{ Komposisi Proksimat (\%) } & \multicolumn{2}{c}{ Umur Panen } \\
\cline { 2 - 4 } & $\mathrm{K} 1$ & $\mathrm{~K} 2$ & $\mathrm{~K} 3$ \\
\hline Air (bb) & $13,01 \pm 0,07^{\mathrm{a}}$ & $12,33 \pm 0,53^{\mathrm{a}}$ & $75,53 \pm 0,65$ \\
Abu (bk) & $4,85 \pm 0,03^{\mathrm{a}}$ & $4,77 \pm 0,06^{\mathrm{a}}$ & $5,01 \pm 0,21$ \\
Lemak (bk) & $15,40 \pm 0,06^{\mathrm{b}}$ & $13,49 \pm 0,11^{\mathrm{a}}$ & $6,94 \pm 0,41$ \\
Protein (bk) & $38,91 \pm 0,06^{\mathrm{a}}$ & $40,70 \pm 0,33^{\mathrm{b}}$ & $19,62 \pm 2,83$ \\
Karbohidrat (bk) & $40,82 \pm 0,11^{\mathrm{a}}$ & $41,02 \pm 0,38^{\mathrm{a}}$ & $68,41 \pm 3,20$ \\
Total fenol (mg GAE/g sampel (bk) & $7,67 \pm 0,29^{\mathrm{b}}$ & $5,31 \pm 0,22^{\mathrm{a}}$ & $59,42 \pm 2,39$ \\
\hline
\end{tabular}

Keterangan: Nilai ditulis sebagai rata-rata $\pm S D(n=3)$, huruf yang berbeda pada satu kolom menunjukkan perbedaan yang signifikan $(P<0,05)$. K1= biji kecipir umur panen 8 minggu, $\mathrm{K} 2=$ biji kecipir umur panen 12 minggu dan $\mathrm{K} 3=$ biji kecipir umur panen 6 minggu sejak tanaman muncul bunga pertama kali 
Biji kecipir umur panen 8 minggu (K1) memiliki kandungan total fenol yang lebih tinggi yaitu sebesar 7,67 mg GAE/g sampel (bk) dibandingkan dengan biji kecipir umur panen 12 minggu (K2) sebesar 5,31 mg GAE/g sampel (bk). Dari hasil tersebut maka dapat dikatakan bahwa pada penelitian ini kandungan total fenol pada biji kecipir semakin menurun dengan semakin lama umur panen. Hasil yang sama juga dilaporkan oleh Persic et al. (2018), kandungan total fenol pada biji kenari semakin menurun seiring semakin lamanya umur panen. Namun pola yang berbeda dilaporkan oleh Mhamdi et al. (2010) dan Kędzierski et al. (2016). Kandungan total fenol pada biji borage dan Aesculum hippocastanum meningkat hingga pada level kematangan tertentu dan kemudian mengalami penurunan.

Biji kecipir dengan umur panen 8 minggu (K1) dan 12 minggu (K2) memiliki kandungan total fenol yang jauh lebih rendah apabila dibandingkan dengan biji kecipir segar (K3). Biji kecipir umur panen 6 minggu (K3) memiliki kandungan total fenol sebesar $59,42 \mathrm{mg} \mathrm{GAE} / \mathrm{g}$ sampel (bk). Pada penelitian ini, biji kecipir memiliki kandungan total fenol yang lebih rendah apabila dibandingkan dengan polong tanaman kecipir. Polong tanaman kecipir dilaporkan memiliki kandungan total fenol sebesar 93,59 $\mu \mathrm{g} \mathrm{GAE} / \mathrm{mg}$ ekstrak (Mustafa et al., 2010). Tanaman kecipir memiliki senyawa flavonoid berupa senyawa katekin, epikatekin, kuersetin, dan myrisetin, tetapi tidak memiliki senyawa flavonoid jenis kaempferol, apigenin, luteolin, dan naringenin (Mustafa et al., 2010). Kandungan asam quinat dan katekin menurun dengan semakin lamanya umur panen biji kenari (Persic et al., 2018), sementara itu kandungan antosianin pada kacang kedelai hitam dilaporkan menurun pada umur panen yang lebih lama (Lee et al., 2013). Senyawa antosianin akan terpusat pada kulit biji selama pertumbuhan dan pematangan biji, sehingga antosianin menjadi lebih tidak stabil disebabkan oleh kondisi yang tidak menguntungkan seperti terjadinya dehidrasi pada biji (Lee et al., 2013). Berdasarkan hal tersebut, maka terjadinya penurunan kandungan total fenol pada biji kecipir dimungkinkan karena adanya perubahan konsentrasi senyawa fenolik dari golongan flavonoid seperti pada katekin dan antosianin yang terdapat pada biji kecipir selama proses pertumbuhan dan pematangan biji. Penurunan senyawa antosianin dapat dikorelasikan dengan terjadinya penurunan kadar air pada biji karena antosianin merupakan senyawa yang larut dalam air. Pada umur panen yang lebih lama, kadar air biji kecipir diketahui semakin menurun, sehingga hal ini dimungkinkan berkontribusi terhadap terjadinya penurunan kandungan total fenol pada biji.

\section{Aktivitas antioksidan}

Antioksidan dalam pangan diartikan sebagai enzim atau senyawa organik dalam pangan yang secara signifikan dapat meredam efek negatif dari reaktif oksigen spesies dan reaktif nitrogen spesies dalam tubuh. Senyawa yang memiliki sifat sebagai antioksidan dilaporkan dapat menurunkan tingkat radikal bebas, tingkat penurunan dari TNF- $\alpha$ dan berkontribusi untuk mencegah berbagai penyakit kronis seperti kanker, kardiovaskular, dan diabetes (Mustafa et al., 2010; Mardiah et al., 2015). Aktivitas antioksidan pada penelitian ini ditunjukkan dengan nilai $I_{50}$ yang menyatakan nilai konsentrasi sampel yang dapat menurunkan aktivitas DPPH sebanyak $50 \%$.

Pada penelitian ini didapatkan nilai $\mathrm{IC}_{50}$ yang lebih tinggi pada biji kecipir umur panen 8 minggu (K1) sebesar $558,33 \mu \mathrm{g} / \mathrm{mL}$ dibandingkan dengan biji kecipir umur panen 12 minggu (K2) sebesar $511,12 \mu \mathrm{g} / \mathrm{mL}$. Biji kecipir segar dengan umur panen 6 minggu (K3) digunakan sebagai pembanding dan memiliki nilai $\mathrm{IC}_{50}$ sebesar $485,67 \mu \mathrm{g} / \mathrm{mL}$ (Gambar 2). Semakin rendah nilai $I_{50}$ menunjukkan semakin tinggi aktivitas antioksidan dari suatu bahan, dengan demikian dapat dikatakan bahwa biji kecipir umur panen 12 minggu (K2) memiliki aktivitas antioksidan yang lebih tinggi dibandingkan dengan biji kecipir umur panen 8 minggu (K1). Gambar 2 menunjukkan bahwa perbedaan umur panen memberikan pengaruh nyata terhadap aktivitas antioksidan biji kecipir $(P<0,05)$. Beberapa penelitian lain melaporkan hal yang serupa, perbedaan umur panen memengaruhi aktivitas antioksidan pada biji borage dan biji Aesculum hippocastanum (Mhamdi et al., 2010; Kedzierski et al., 2016). Jeon et al. (2017) melaporkan aktivitas antioksidan pada biji sorghum mengalami penurunan mulai dari umur panen 25 hingga 55 hari. Penurunan aktivitas antioksidan pada sorghum ini berkolerasi dengan terjadinya penurunan kandungan total fenol, total flavonoid dan tanin pada biji sorgum. Singh et al. (2019), melaporkan bahwa kapasitas antioksidan pada tanaman kecipir berkisar antara 0,66-5,02 $\mu \mathrm{mol} / \mathrm{g}$ berat segar, sementara itu biji kedelai hitam dilaporkan memiliki kapasitas antioksidan sebesar 144,06 mg AEAC (Zakaria et al., 2016).

Hubungan antara aktivitas antioksidan dan total fenol berdasarkan analisis korelasi Pearson pada penelitian ini menunjukkan adanya korelasi yang negatif. Hal ini terlihat dari nilai $r$ yang didapatkan yaitu sebesar $-0,969 \quad(P<0,05)$. Kandungan total fenol pada biji kecipir mengalami penurunan dengan semakin lama umur panen, sedangkan aktivitas antioksidan $\left(\mathrm{IC}_{50}\right)$ biji kecipir mengalami kenaikan dengan semakin lama umur panen. Aktivitas antioksidan bergantung kepada senyawa alami pada bahan, tetapi tidak berkitan secara spesifik dengan senyawa fenolik pada bahan (Mhamdi et al., 2010). Oleh karena itu, peningkatan aktivitas antioksidan biji kecipir pada penelitian ini dapat berasal dari komponen alami selain senyawa fenolik seperti komponen vitamin. Erbesdobler et al. (2017) melaporkan bah- 
wa pada kacang-kacangan memiliki kandungan senyawa pembentuk vitamin seperti $\alpha$-tocopherol, $\mathrm{y}^{-}$ tocopherol, thiamine, riboflavin, pyridoxine dan folat. Senyawa fenolik yang dianalisis menggunakan metode Folin-Ciocalteu spesifik terhadap senyawa fenolik pada bahan sedangkan untuk aktivitas antioksidan dengan metode DPPH memberikan hasil yang tidak spesifik hanya terhadap senyawa fenolik pada bahan (Prior et al., 2005).

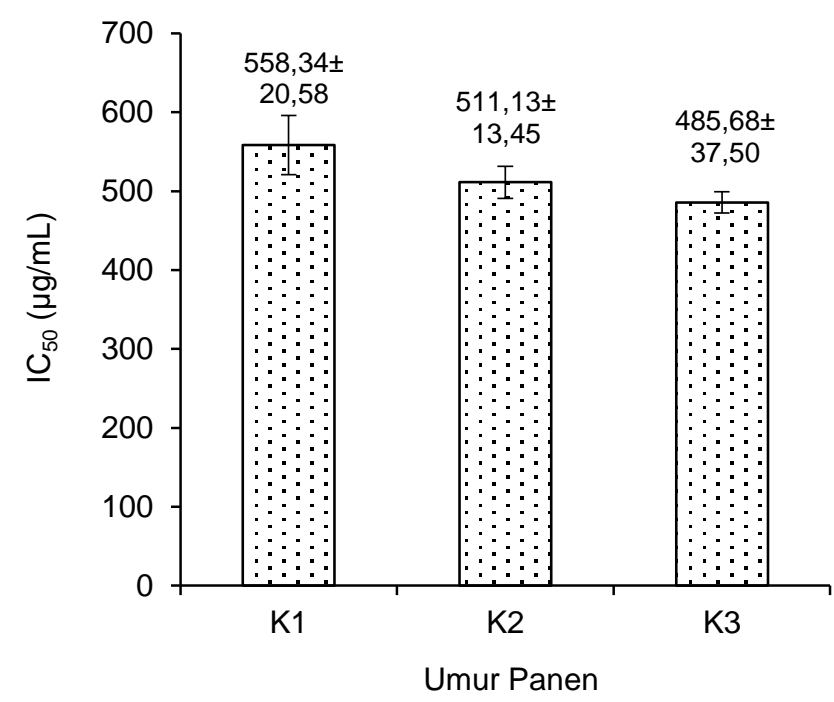

Keterangan: $\mathrm{K} 1=$ biji kecipir umur panen 8 minggu, $\mathrm{K} 2=$ biji kecipir umur panen 12 minggu dan $\mathrm{K} 3=$ biji kecipir umur panen 6 minggu sejak tanaman muncul bunga pertama kali

Gambar 2. Aktivitas antioksidan $\left(\mathrm{IC}_{50}\right)$ biji kecipir pada berbagai umur panen

\section{Total pati dan gula pereduksi}

Sintesis pembentukan pati merupakan aktivitas biosintesis dasar pada tahap perkembangan biji (Dai, 2010). Hasil analisis kadar total pati dan gula pereduksi dapat dilihat pada Gambar 3. Kadar total pati pada biji kecipir umur panen 8 minggu (K1) dan 12 minggu (K2) secara berturut-turut sebesar 29,14 dan $25,67 \%$. Uji Duncan menunjukkan bahwa perbedaan umur panen 8 minggu (K1) dan 12 minggu (K2) tidak memberikan pengaruh beda nyata $(P>0,05)$ terhadap total pati biji kecipir. Secara umum, kadar total pati mengalami penurunan dari umur panen 8 minggu (K1) hingga umur panen 12 minggu (K2). Total pati kedua sampel didapatkan jauh lebih tinggi apabila dibandingkan dengan total pati pada biji kecipir muda dengan umur panen 6 minggu (K3) yaitu sebesar 7,26\%. Siddique dan Wright (2003) menyatakan bahwa sintesis pati akan dimulai pada tahap awal setelah tanaman berbunga. Oleh karena itu, hal ini diduga yang menyebabkan biji kecipir umur panen 6 minggu (K3) memiliki total pati terendah dan kemudian meningkat secara signifikan pada umur panen yang lebih lama. Berdasarkan hasil penelitian, total pati pada biji kecipir dengan berbagai umur panen lebih rendah apabila dibandingkan dengan kacang hijau tetapi lebih tinggi apabila dibandingkan dengan kedelai. Triwitono et al. (2017) melaporkan bahwa 4 varietas dari kacang hijau memiliki kandungan total pati berkisar antara 40-43\%, sedangkan Alamu et al. (2017) melaporkan bahwa 6 varietas kedelai memiliki kandungan total pati sebesar $12-17 \%$.

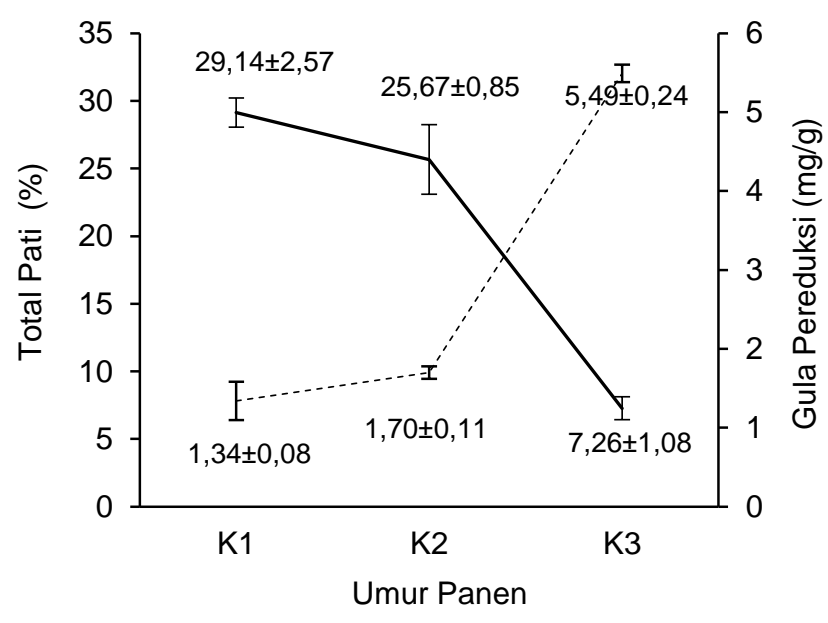

$$
\text { — Total Pati -..-.-.- Gula Pereduksi }
$$

Keterangan: $\mathrm{K} 1=$ biji kecipir umur panen 8 minggu, $\mathrm{K} 2=$ biji kecipir umur panen 12 minggu dan $\mathrm{K} 3=$ biji kecipir umur panen 6 minggu sejak tanaman muncul bunga pertama kali

Gambar 3. Total pati dan gula pereduksi biji kecipir pada berbagai umur panen

Kadar gula pereduksi pada penelitian ini didapatkan berkisar antara 1,34-5,49 mg/g. Secara umum, kadar gula pereduksi pada biji kecipir mengalami sedikit kenaikan pada umur panen 8 minggu (K1) hingga umur panen 12 minggu (K2). Hasil ini tidak berbeda jauh dengan kandungan gula reduksi pada kacang kedelai. Kandungan gula reduksi (fruktosa, glukosa, maltosa) pada kacang kedelai matang berkisar antara $0,25-5,76 \mathrm{mg} / \mathrm{g}$ pada 4 varietas berbeda (Obendorf et al., 2011). Sukrosa diketahui merupakan komponen gula dominan yang dimiliki oleh 3 jenis kacang (dark bean, dark red bean, cranberry bean) dari varietas Phaseolus vulgaris (L.), sementara itu fruktosa, glukosa, maltosa dan galaktosa yang tergolong dalam gula pereduksi terdapat pada jumlah yang kecil (John dan Luthria, 2015). Terdapatnya sedikit kenaikan gula pereduksi pada umur panen 12 minggu (K2) diduga karena terjadinya konversi pati menjadi gula untuk keperluan germinasi disebabkan karena biji umur panen 12 minggu (K2) mendekati tahap menjadi bibit dari tanaman kecipir. Hal ini sesuai dengan yang dinyata- 
kan oleh Zhao et al. (2018), kandungan gula memiliki korelasi positif dengan kandungan pati pada biji yang mengalami germinasi dimana pati akan terhidrolisis menjadi gula.

\section{KESIMPULAN}

Perbedaan umur panen memberikan pengaruh nyata terhadap karakteristik kimia biji kecipir yakni atas komposisi proksimat, kandungan total fenol, aktivitas antioksidan, dan kadar gula pereduksi $(P<0,05)$. Apabila dilihat dari faktor efisiensi waktu, biji kecipir umur panen 8 minggu (K1) memiliki waktu yang lebih singkat untuk panen dibandingkan dengan biji kecipir dengan umur panen 12 minggu (K2) sehingga lebih memudahkan dalam memperoleh dan efisensi waktu bahan baku. Secara keseluruhan, biji kecipir umur panen 8 minggu (K1) dan 12 minggu (K2) memiliki komposisi proksimat dan total pati yang lebih tinggi dari biji kecipir umur panen 6 minggu (K3), tetapi memiliki nilai yang lebih rendah pada kandungan total fenol, aktivitas antioksidan dan gula pereduksi. Biji kecipir yang dipanen pada kondisi $\mathrm{K} 1$ dan $\mathrm{K} 2$ memiliki kandungan protein yang tinggi (38,91 dan 40,70\% bk). Hal ini memberikan peluang bahwa biji kecipir dapat dijadikan sebagai sumber protein. Dengan demikian, pada penelitian ini menunjukkan bahwa potensi biji kecipir sebagai sumber pangan sangat erat kaitannya dengan pemanfataannya. Secara khusus, biji kecipir dengan umur panen 8 minggu (K1) berpotensi untuk dikembangkan sebagai produk pangan fungsional ready to eat, susu biji kecipir, tahu biji kecipir dan produk olahan lainnya dari tepung biji kecipir.

\section{UCAPAN TERIMA KASIH}

Terimakasih kepada LPPM IPB dan Kemenristek-Dikti yang telah mendanai penelitian ini melalui Penelitian Terapan Unggulan Perguruan Tinggi Tahun 2018 (1658/IT3.11/PN/2018).

\section{DAFTAR PUSTAKA}

Alamu EO, Therese G, Mdziniso P, Bussie MD. 2017. Assessment of nutritional characteristics of products developed using soybean (Glycine max (L.) Merr.) pipeline and improved varieties. Cogent Food Agric 3: 1-12. DOI: 10.1080/2331 1932.2017.1398042.

Aldillah R. 2015. Proyeksi produksi dan konsumsi kedelai Indonesia. J Ekonomi Kuantitatif Terapan 8: 9-23.
[AOAC] Association of Official Analytical Chemist. Official Method 2003.06. 2012. Crude Fat in Feeds, Cereal Grains and Forages. Chapter 4. 43. Official Methods of Analysis of AOAC International 19th ed., AOAC International Gaithersburg, MD, USA.

[AOAC] Association of Official Analytical Chemist. Official Method 950.48. 2012. Protein (Crude) in Nuts and Nut Products: Improved Kjeldahl Method. Chapter 40. 2. Official Methods of Analysis of AOAC International $19^{\text {th }}$ ed., AOAC International Gaithersburg, MD, USA.

Başkan KS, Tütem E, Akyüz E, Özen S, Apak R. 2016. Spectrophotometric total reducing sugars assay based on cupric reduction. Talanta 147: 162-168. DOI: 10.1016/j.talanta.2015.09.049.

[BPS] Badan Pusat Statistik. 2017. https://www.bps. go.id. [19 Maret 2017].

[BSN] Badan Standarisasi Nasional. 1992. SNI 012891-1992 Cara Uji Makanan dan Minuman. Jakarta: Badan Standarisasi Nasional.

Budijanto S, Sitanggang AB, Wita M. 2011.Karakterisasi sifat fisiko-kimia dan fungsional isolat protein biji kecipir (Psophocarpus tetragonolubus L.). J Teknol Industri Pangan 22: 130-136.

Clegg KM. 1956. The application of the anthrone reagent to the estimation of starch in cereals. $J$ Sci Food Agric 7: 41-44. DOI: 10.1002/jsfa.274 0070108.

Dai Z. 2010. Activities of enzymes involved in starch synthesis in wheat grains differencing in starch content. Russ J Plant Physl+ 57:74-78. DOI: 10.1134/S1021443710010103.

Handayani T, Kusmana, Lukman L Hidayat IM. 2015. Karakterisasi morfologi dan evaluasi daya hasil sayuran polong kecipir (Psophocarpus tetragonolubus (L) DC). J Hort 25: 126-132. DOI: 10.21082/jhort.v25n2.2015.p126-132.

Hodzic Z, Pasalic H, Memisevic A, Srabovic M, Saletovic M, Poljakovic M. 2009. The influence of total phenols content on antioxidant capacity in the whole grain extracts. Eur J Sci Res 28: 471-477.

Horax R, Hettiarachchy N, Kannan A, Chen P. 2010. Proximate composition and amino acid and mineral contents of Mormordica charantia L. pericarp and seeds at different maturity stages. Food Chem 122: 1111-1115. DOI: 10.1016/j. foodchem.2010.03.093.

Jeon SH, Ki IS, Park SK, Jung KY, Kim SW, Cho YS. 2017. Dependence of sorghum bicolor antioxidant activity on harvest time. ScienceAsia 43: 155-162. DOI: 10.2306/scienceasia1513-18 74.2017.43.155. 
John KMM, Luthria D. 2015. Amino acid, organic acid, and sugar profiles of 3 dry bean (Phaseolus vulgaris L.) varieties. J Food Sci 80: C2662C2669. DOI: 10.1111/1750-3841.13115.

Kędzierski B, Kukula-Koch W, Widelski J, Głowniak K. 2016. Impact of harvest time of Aesculum hippocastanum seeds on the composition, antioxidant capacity and total phenolic content. Ind Crop Prod 86: 68-72. DOI: 10.1016/j.indcrop.20 16.03.034.

Kementrian Pertanian. 2015. Outlook komoditas pertanian subsektor tanaman pangan kedelai. Pusat Data dan Sistem Informasi Pertanian.

Koley TK, Singh S, Khemariya P, Sarkar A, Kaur C, Chaurasia SNS, Naik PS. 2014. Evaluation of bioactive properties of Indian carrot (Daucus carota L.): A chemometric approach. Food Res Int 60: 76-85. DOI: 10.1016/j.foodres.2013.12. 006.

Lee JH, Cho KM. 2012. Changes occurring in compositional components of black soybeans maintained at room temperature for different storage periods. Food Chem 131: 161-169. DOI: 10.101 6/j.foodchem.2011.08.052.

Lee J, Hwang YS, Chang WS, Moon JK, Choung MG. 2013. Seed maturity differentially mediates metabolic responses in black soybean. Food Chem 141: 2052-2059. DOI: 10.1016/j.food chem.2013.05.059.

Makeri M, Sahri MM, Ghazali HM, Ahmad K, Muhammad K. 2019. Polymorphism, textural and crystallization properties of winged bean (Psophocarpus tetragonolobus, D.C) oil-based trans-fatty acids free ternary margarine blends. LWT-Food Sci Technol 100: 158-166. DOI: 10.1 016/j.Iwt.2018.09.012.

Mardiah, Zakaria FR, Prangdimurti E, Damanik R. 2015. Anti-inflammatory of purple roselle extract in diabetic rats induced by streptozotocin. Proc Food Sci 3: 182-189. DOI: 10.1016/j.profoo.20 15.01.020.

Mhamdi B, Wannes WA, Sriti J, Jellali I, Ksouri R, Marzouk B. 2010. Effect of harvesting time on phenolic compounds and antiradical scavenging activity of Borago officinalis seed extracts. Ind Crop Prod 31: e1-e4. DOI: 10.1016/j.ind crop.2009.07.002.

Mohanty CS, Verma S, Singh V, Khan S, Gaur P, Gupta P, Nizar MA, Dikshit N, Pattanayak R, Shukla A, Niranjan A, Sahu N, Behera SK, Rana TS. 2013. Characterization of winged bean (Psophocarpus tetragonolubus (L) DC) based on molecular, chemical and physiological parameters. Am J Mol Biol 3: 187-197. DOI: 10.423 6/ajmb.2013.34025.
Mohtar WAAIW, Hamid AA, Abd-Aziz S, Muhamad SKS, Saari N. 2014. Preparation of bioactive peptides with high angiotensin converting enzyme inhibitory activity from winged bean ( $P$ sophocarpus tetragonolobus (L) DC) seed. J Food Sci Technol 51: 3658-3668. DOI: 10.1007/s131 97-012-0919-1.

Mustafa RA, Abdul H, Mohamed S, Bakar A. 2010. Total phenolic compounds, flavonoids, and radical scavenging activity of 21 selected tropical plants. J Food Sci 75: 28-35. DOI: 10.1111/j.17 50-3841.2009.01401.x.

Obendorf, Ralph L, dan Kosina SM. 2011. Soluble Carbohydrates in Soybean, Soybean-Biochemistry, Chemistry and Physiology.201-228. Intech Europe, University Campus Step RI, Croatia. DOI: 10.5772/15110.

Ogumo EO, Kunyanga CN, Kimenju JW, Okoth MW. 2018. Effect of harvest time and duration before cooling on the post-harvest quality and shelf life stability of french bean (Phaseolus vulgasris L.). J Nutr Food Sci 8: 1-6. DOI: 10.4172/21559600.1000730.

Pal M, Brahmachary RL, Ghosh M. 2010. Comparative studies on physicochemical and biochemical characteristics of scented and non-scented strains of mung beans (Vigna radiate) of Indian origin. Legume Res 33: 1-9.

Palupi NS, Sitorus SR, Kusnandar F. 2015. Perubahan alergenisitas protein kacang kedelai dan kacang bogor akibat pengolahan dengan panas. J Teknol Industri Pangan 26: 222-231. DOI: 10.6066/jtip.2015.26.2.222.

Panahi B, Kherzi M. 2011. Effect of harvesting time on nut quality of pistachio (Pistarica vera L.) cultivars. Sci Hortic-Amsterdam129: 730-734. DOI: 10.1016/j.scienta.2011.05.029.

Persic M, Mikulic-Petkovsek M, Slatnar A, Solar A, Veberic R. 2018. Changes in phenolic of redcolored pellicle walnut and hazelnut kernel during ripening. Food Chem 252: 349-355. DOI: 10.1016/j.foodchem.2018.01.124.

Prior RL, Wu X, Schaich K. 2005. Standardized methods for the determination of antioxidant capacity and phenolics in foods and dietary supplements. J Agric Food Chem 53: 4290-4302. DOI: 10.1021/jf0502698.

Salazar-Aranda R, Pérez-López LA, López-Arroyo J, Alanís-Garza BA, de Torres NW. 2011. Antimicrobial and antioxidant activities of plants from Northeast of Mexico. Evid-Based Compl Alt 2011: 1-6. DOI: 10.1093/ecam/nep127. 
Saldivar X, Wang YJ, Chen P, Hou A. 2011. Change in chemical composition during soybean seed development. Food Chem 124: 1369-1375. DOI: 10.1016/j.foodchem.2010.07.091.

Siddique AB, Wright D. 2003. Effect of different time and temperature on moisture percentage and seed quality (viability and vigour) of pea seeds (Pisum sativum L.). Asian J Plant Sci 2: 978982. DOI: 10.3923/ajps.2003.978.982.

Singh M, Dubey RK, Koley TK, Maurya A, Singh PM, Singh B. 2019. Valorization of winged bean (Psophocarpus tetragonolobus (L) DC) by evaluation of its antioxidant activity through chemometric analysis. S Afr J Bot 121: 114-120. DOI: 10.1016/j.sajb.2018.10.026.

Triwitono $\mathrm{P}$, Marsono $\mathrm{Y}$, Murdiati A, Marseno DW. 2017. Isolasi dan karakterisasi sifat pati kacang hijau (Vigna radiata L.) beberapa varietas lokal Indonesia. Agritech 37: 192-198. DOI: 10.2214 6/agritech.10659.

Wahyuni S. 2010. Karakterisasi Senyawa Bioaktif Isoflavon dan Uji Aktivitas Antioksidan dari Ekstrak Tempe Berbahan Baku Buncis dan Kecipir [Tesis]. Surakarta: Fakultas Pertanian, Universitas Sebelas Maret.

Wawire M, Oey I, Mathooko FM, Njoroge CK, Shitanda D, Sila D, Hendrickx M. 2012. Effect of harvest age and thermal processing on poly- $\gamma$ glutamate folates and minerals in African cowpea leaves (Vigna unguiculata). J Food Compos Anal 25: 160-165. DOI: 10.1016/j.jfca.2011. 11.003.
Wijaya C, Leonardus BSK, Jeremia MH. 2015. Peningkatan akseptabilitas susu kecipir (Psophocarpus tetragonolobus (L.) DC.) dengan adisi bahan penstabil dan jus jahe. J Aplikasi Teknol Pangan 4: 112-123. DOI: 10.17728/jatp.1.

Yea CS, Ebrahimpour A, Hamid AA, Bakar J, Muhammad K, Saari N. 2014. Winged bean (Psophocarpus tetragonolobus (L). DC) seeds as an underutilised plant source of bifunctional proteolysate and biopeptides. Food Funct 5: 10071016. DOI: 10.1039/c3fo60667h.

Yea CS, Salleh A, Sulaiman NF, Abidin NZ, Hanafi MA, Zarei M, Saari N. 2018. Blood pressure lowering efficacy of winged bean seed hydrolysate in spontaneously hypertensive rats, peptide characterization and toxicity study in Sprague-Dawley rats. Food Funct 9: 1-42. DOI: 10.1039/C7FO01769C.

Zakaria FR, Prangdimurti E, Puspawati GAKD, Thahir R, Suismono. 2011. Diet berbasis sorgum (Sorghum bicolor L Moench) memperbaiki proliferasi limfosit limfa dan kapasitas antioksidan hati tikus. J Pangan 20: 209-222.

Zakaria FR, Firdaus DPR, Yuliana ND. 2016. Konsumsi tahu kedelai hitam untuk memperbaiki nilai SGOT/SGPT dan aktivitas antioksidan plasma penderita diabetes tipe 2. J Pangan 25: 95104.

Zhao M, Zhang H, Yan H, Qu L, Baskin CC. 2018. Mobilization and role of starch, protein, and fat reserves during seed germination of six wild grassland species. Front Plant Sci 9: 1-11. DOI: 10.3389/fpls.2018.00234. 